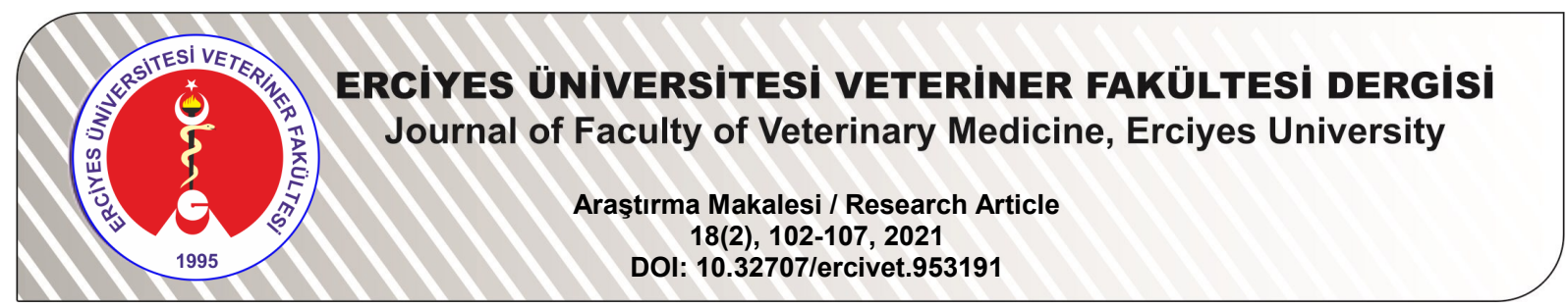

\title{
İç Anadolu Bölgesi Şartlarında Siyah Alaca ve Simental Irkı İneklerde Mastitis ve Metritis Görülme
} Oranları ${ }^{*, * *}$

\author{
Mustafa ÇAM ${ }^{1, a}$, Şeref iNAL $L^{1, b}$ \\ ${ }^{1}$ Selçuk Üniversitesi, Veteriner Fakültesi, Zootekni Anabilim Dalı, Konya-TÜRKIYE
}

ORCID No: a0000-0002-1821-191X; ${ }^{b} 0000-0003-4746-8930$

Sorumlu yazar: Mustafa ÇAM; E-posta: mustafa.cam@selcuk.edu.tr

Atıf yapmak için: Çam M, İnal Ş. İç Anadolu Bölgesi şartlarında Siyah Alaca ve Simental ırkı ineklerde mastitis ve metritis görülme oranları. Erciyes Univ Vet Fak Derg 2021; 18(2): 102-107

Öz: Bu çalışmada; Türkiye'nin İç Anadolu Bölgesinde yer alan özel bir işletmede yetiştirilen Siyah Alaca ve Simental ırkı sığırlarda metritis ve mastitis görülme oranları incelenmiştir. Hastalıkların görülme sıklığını etkileyen ırk, yaş ve yıl faktörlerinin değerlendirilmesi yapılmıştır. Çalışmanın materyalini 2013-2017 yıllarında işletmede bulunan 4164 baş Siyah Alaca ve 892 baş Simental dişi sığırlara ait veriler oluşturulmuştur. İşletmedeki dişi sığırlar yaş kategorilerine göre düve ve inek $(2,3,4,5,6$ ve üzeri) olarak sınıflandırılmıştır. Hastalık oranları hesaplanırken incelenen tarihler arasında ilgili yaşa ait toplam hayvan sayısı ile ilgili hastalığa en az bir kere yakalanan hayvan sayısı kullanılmıştır. Mastitisin yaşla birlikte arttığı; metritisin ise 3 yaş altı ve 6 yaş üstü ineklerde arttığı görülmüştür. Siyah Alaca ırkı sığırların Simentallere göre mastitis ve metritise yakalanma eğiliminin daha yüksek olduğu tespit edilmiştir.

Anahtar kelimeler: Insidans, mastitis, metritis, süt sığırcılığı

Mastitis and Metritis Rate in Holstein and Simmental Cows under the Central Anatolia Conditions

Abstract: The study was evaluated to detect metritis and mastitis rates of dairy cows with different age groups and breeds in an intensive dairy farm located in the Central Anatolian Region of Turkey. The data from 4164 Holstein and 892 Simmental cows between 2013-2017 were allocated to different age groups such as heifers, cows $(2,3,4,5,6+$ years). The exposed groups with related risk age which the relative diseases were detected at least once during the risk period were contributed to the nominator while all population with the related risk age were contributed to the denominator when calculating proportions for morbidity rates in excel worksheets. The chi-square test was used to determine statistical differences of the factors. Mastitis rate was found to be more widespread in older cows while mastits rate was found to be more common in those younger than 3 years of age and older than 6 years of age. Holstein cows tended to be more sensitive to the metritis and mastitis. With obtaining remarkable significant results, the multiparous cows were seen prone to higher morbidity rates.

Keywords: incidence rate, mastitis, metritis, dairy cattle

\section{Giriş}

Meme dokusunun enfeksiyöz yangısı olan mastitis, hayvanlarda refahı olumsuz yönde etkiler ve büyük ekonomik kayıplara sebep olur. Genel olarak klinik ve subklinik olmak üzere 2'ye ayrılmaktadır. Klinik mastitis meme bezinde kızarıklık, şişkinlik, ağrı, genel durum bozukluğu ve sütün yapısının değişmesiyle gözle teşhis edilebilirken, subklinik mastitis ise sütteki somatik hücre sayısına bağlı olarak gelişir ve herhangi bir klinik bulgu oluşturmaz (Contreras ve Rodriguez, 2011). Yapılan bir çalışmada ineklerde mastitisin yaşla beraber arttığı bildirilirken (Suthar ve ark., 2013); başka bir çalışmada ise ilkine doğuran ineklerde daha fazla mastitis görüldüğü bildirilmiştir (Parker

\begin{tabular}{ll}
\hline Geliş Tarihi/Submission Date & $: 28.12 .2020$ \\
Kabul Tarihi/Accepted Date & $: 01.06 .2021$
\end{tabular}

* Bu çalışma İzmir, Türkiye'de Uluslararası Ege Sempozyumunda 18 -20 Eylül 2020 sözlü sunu (özet) olarak sunulmuştur.

** Bu çalışma başlıca yazarın doktora tezinin bir bölümünden özetlenerek hazırlanmıştır. ve ark., 2007).

Klinik mastitis görülme sıklığı ülkelere, bölgelere, sürülere, ahır tipi, bakım ve besleme gibi çevresel faktörlere bağlı olarak değişmektedir. Kanada'da 10 farklı bölgeden elde edilen sonuçlara göre her 100 inekten 23'ünde klinik mastitis görülmektedir (Riekerink ve ark., 2008). Hossein-Zadeh ve Ardalan (2011), 57301 veriyi inceledikleri İran'da klinik mastitis insidansını \%8.9 olarak bulmuşlardır. Yeni Zelanda'da merada serbest dolaşan hayvanlarda klinik mastitis insidansı \%9.9 ve \%14.8 olarak belirlenmiştir (McDougall, 1999; Petrovski ve ark., 2009). Avusturalya'da 8 farklı sürüde \%16 (Stevenson, 2000) ve Kanada'da \%10.1 olarak hesaplanan klinik mastitis insidansı (Kelton ve ark., 1998); Avrupa'daki 10 ülkeden elde edilen verilere göre \%6.1 olarak bulunmuştur.

Piepers ve ark. (2007), Belçika'daki subklinik mastitis insidansını araştırmışlar ve ineklerin 2000 'de \%39 ve 
2002'de \%18'inin subklinik mastitis olduğunu belirtmişlerdir. Roesch ve ark. (2007), İsveç'te organik ve geleneksel yetiştiricilik yapan sürülerdeki hayvanların subklinik mastitis insidanslarını \%39.4 ve \%34.2 olarak bulmuşlardır.

Türkiye'de de mastitis insidansını belirlemeye yönelik çalışmalar yapılmıştır. Bulunan farklı sonuçlar, çalışmaların yapıldığı iller, bakım, besleme, çalışmada uygulanan metotlar, çalışmanın yapıldığı ırklar, işletme ve ahır tipindeki farklılıklara dayandırılabilir. Alaçam ve ark. (1989), ineklerde subklinik mastitis görülme sıklığının \%6.73 ile 17.25 arasında değişmekte olduğunu belirtmişlerdir. Afyon civarında ise subklinik mastitis görülme sıklığı \%43 olarak bulunmuştur (Kuyucuoğlu ve Uçar, 2001). Kars'ta ise Simental ineklerde bu oran \%15.78 olarak bulunmuştur (Şahin ve ark., 1997). Şanlıurfa'da daha çok temizliğe dikkat edilmediği ve çiftçilerin sağımla ilgili yeteri kadar bilgilerinin olmadığı aile tipi işletmelerden elde edilen veriler incelendiğinde subklinik mastitis görülme sıklığı \%72.4 olarak bulunmuştur (Tel ve ark., 2009).

Süt verimini ve döl verimini ciddi şekilde etkileyen metritis; serviksin, uterus boşluğunun ve kas katmanlarının yangısıdır. Sürülerde metritis görülme oranı sürü büyüklüğüne, hayvanın bağışıklık sistemine ve mikropların patojenitesine bağlı olarak değişmektedir. Genel olarak doğumdan sonra ilk 2 haftada sığırların \%25-40'ında görülen metritis klinik olarak; \%20'lik bir insidansla endometritis olarak devam eder (Sheldon ve ark., 2008). Bartlett ve ark. (1986), 3773 laktasyona ait verileri incelemişler ve metritis insidansını \%18 olarak bulmuşlardır. Metritisin daha çok postpartum ilk 3 haftada görüldüğünü bildirmişlerdir. Kanada'da yapılan bir araştırmada metritis insidansı \%10.1 olarak bulunmuştur (Kelton ve ark., 1998). Bruun ve ark. (2002), metritis insidansını \%0.7 olarak bulmuşlardır. Metritis insidansını etkileyen faktörlerin; yaş, otlama, buzağılama mevsimi, güç doğum, döl verimi hastalıkları, ketozis, retensiyo ve ırk olduğunu belirtmişlerdir. Özellikle retensiyo sekundinarum metritisin en önemli faktörlerinden biridir (LeBlanc, 2008). Doğum zorluğu ve problemleri yaşayan inekler ve düveler ile kış aylarında buzağılayanların metritise yakalanma riski daha yüksek bulunmuştur (Hossein-Zadeh ve Ardalan, 2011). LeBlanc (2008), 27 sürüdeki 1865 ineğe ait verileri incelemiş ve endometritis insidansını \%16.9 bulmuştur. Benzaquen ve ark. (2007), Florida'da puerperal metritis ile klinik endometritis insidanslarını \% 21 ve \%24 olarak bulmuşlardır. Suthar ve ark. (2013) tarafından 10 Avrupa ülkesinde yapılan araştırmada $\% 9.6$ olarak bulunan metritis insidansı, Türkiye'de \% 3.7 olarak belirlenmiştir.

Uterus duvarının daha hassas olması (Bruun ve ark., 2002) ve güç doğumun daha fazla görülmesi Sieber ve ark., 1989; Johanson ve Berger, 2003; Lombard ve ark., 2007; Uzmay ve ark., 2010) nedeniyle ilkine doğuran ineklerde metritis riskinin arttığı bildirilmekte- dir. Fakat yapılan bir çalışmada farklı olarak metritis ile doğurma sayısı arasında istatistiki düzeyde önemli ilişki olduğu bildirilmiştir (Markusfeld, 1987).

Mastitis ve metritis görülme oranlarıyla ilgili yapılan çalışmaların hemen hemen hepsinin Siyah Alaca ırkını incelediği görülmekte olup bu konuda ırk karşılaştırıması yapan çalışma sayısının çok kısıtı olduğu görülmektedir. Bu çalışmanın amacı; 2013-2017 yılları arasında İç Anadolu Bölgesinde özel bir işletmede yetiştiriciliği yapılan Siyah Alaca ve Simental ırkı düve ve ineklerdeki mastitis ve metritis hastalıklarının görülme oranlarının tespiti ile bu hastalıklar üzerine etkisi olduğu düşünülen ırk, doğurma sayısı, yıl gibi bazı faktörlerin etkisinin ortaya konulmasıdır.

\section{Gereç ve Yöntem}

Çalışmada kullanılan veriler özel bir işletmede yetiştirilen hayvanlardan elde edilmiştir. Çalışmadaki hayvan materyali üzerine herhangi bir deney ve ek işlem yapılmamıştır. Bu nedenle gerekli izin belgesi alınarak (SÜVDAMEK 2019/14) etik kurul tarafından onaylanmıştır.

\section{İşletme koşulları}

Çalışmanın yapıldığı işletme bozkır ikliminin hakim olduğu İç Anadolu Bölgesinde yer almakta olup 1200 metre rakımda ve etrafı dağlarla çevrilidir. Yıllık sıcaklık ortalaması $10{ }^{\circ} \mathrm{C}$, yazlar sıcak ve kurak, kışlar soğuk ve yağışlıdır. İşletmede 600 başlık duraksız, serbest dolaşımlı ve yan kısımları perdeli iki sağmal inek ahırı bulunmaktadır. Her bir ahır 150 baş kapasiteli 4 bölmeden oluşmaktadır. İşletmede 2013 yılından 2017 yılına kadar duraksız, serbest dolaşımlı ahır sistemi uygulanmış ve 2017 yılından itibaren duraklı, serbest dolaşımlı ahır yapısına geçilmiştir. İşletmede 2013 yılından beri verimler ve sağlık kayıtları ile ilgili veriler düzenli olarak tutulmuştur. Ayrıca işletmede doğan dişi ve erkek buzağıların çoğunluğu işletmede büyütülmekte ve zaman zaman işletme kapasitesi 2500 baş sığırı geçmektedir. İşletmenin kuruluşunda gerek yurtdışından ve gerekse yurtiçinden temin edilen Siyah Alaca ırkı gebe düveler yer almıştır. Düzenli ve ayrıntılı kayıtların tutulmaya başlandığı 2013 yılı ve sonrasında Simental ırkı gebe düveler de sürüye dahil edilmeye başlanmıştır.

İşletmenin kurulduğu 2011 yılından 2017 yılına kadar bütün hayvanlar, işletme sahiplerinin "İsrail Modeli" olarak tanımladıkları; duraksız, serbest dolaşımlı ve yan kısımları perdeli toprak zeminli padoklarda barındırılmışlardır. Bu dönemde ahır zemininde biriken gübre birkaç ayda bir kamyonlara yüklenerek gübre biriktirme çukuruna atılması yoluyla uzaklaştırılmıştır. 2017 yılından itibaren ise duraklı, serbest dolaşımlı ahırlarda otomatik sıyırıcılı, beton zemin barındırma sistemine geçilmiştir. Ahırların geçirgen perde duvarlı yapısı sürdürülmüştür. 
İşletmede sağmal inekler işletmenin kurulduğundan bu yana $2 \times 24$ sıralı sağım sisteminin yer aldığı sağımhanede sağılmışlardır. Sağılan ineklerden şüphelenilenlere Kaliforniya Mastitis Testi (CMT) uygulanmakta ve 2 haftada bir tüm sürü CMT ile taranmaktadır. Ayrıca sağımhanedeki 10 tonluk 2 tankta depolanan sütlerden alınan tank sütü numunesinde sütü satın alan fabrika somatik hücre sayımı yapmaktadır. Son yıllarda işletmedeki laboratuvara alınan somatik hücre sayımı aleti de kullanılmaya başlanmıştır.

\section{Verilerin toplanması ve sadeleştirilmesi}

Bu çalışmada, 2013-2017 yıllarında işletmeye gebe düve olarak giren, işletmede doğarak büyütülen ve sürüye katılan yaklaşık 4164 baş Siyah Alaca ve 892 baş Simental dişi sığıra ait günlük olarak işletmenin veteriner hekimleri tarafından tutulan mastitis ve metritis kayıtları incelenmiştir. Doğum sayısı bakımından 2834 başı ilkine buzağılayan, 2222 başı ise birden fazla buzağılayan (multipar) ineğin mastitis ve metritis verileri incelenmiştir. Kayıtlar ayrıca, ticari bir sağımhane ve sürü yönetimi programı olan DairyPlan'a düzenli olarak kaydedilmektedir. İşletmede hayvanlara yönelik hastalık teşhisleri, bulgular, tedavide kullanılan ilaçlar ve tedavi sonuçları, işletme veteriner hekimleri ve teknikerleri tarafından düzenli olarak takip edilmekte, DairyPlan programına günlük olarak kaydedilmektedir. Ayrıca bütün bu bilgiler gün sonunda her ay için ayrı bir Microsoft Excel dosyasına düzenli olarak kaydedilmektedir. Bu çalışmada kullanılan veriler Dairyplan programından alınan ve işletmenin düzenli olarak tuttuğu excel kayıtlarından oluşmaktadır.

Araştırmanın veri seti 2013-2017 yılları arasında tutulan verilerin sadeleştirilmesi ve analize uygun hale getirilmesi ile oluşturulmuştur. Bunun için ilk olarak 2013-2017 yılları arasında işletmede yer alan yaklaşık 4164 baş Siyah Alaca ve 892 baş Simental dişi sığırların tanımlanması ve kimlik bilgilerinin derlenmesi çalışmaları yapıımıştır. Bu amaçla işletmede 2013 yılının Ocak ayından başlayarak 2017 yılının sonuna kadar aylık periyodlarla işletmeye yeni alınan damızlık gebe düve ve inekler, doğumu gerçekleşen ve resmi kulak küpeleri takılan dişi buzağıların veri kayıtları incelenerek eksik ve hatalı kayıtlar çalışmaya dahil edilmemiştir. İncelenecek hayvanların doğum tarihi, yaş, sürüden çıkarılma tarihi, cinsiyet, ırk bilgi- leri bir Excel dosyasına girilerek bir veri tabanı oluşturulmuştur.

Kaydı tutulan sığırlar, erginlik düzeylerine göre düve ve inek olarak gruplandırılmıştır. Yaş kriterleri kullanılarak, 365-730 günlük yaştaki sığırlar düve olarak belirlenmişlerdir. İnekler ise yaşlarına göre 731-1095 günlük (2 yaş), 1096-1460 günlük (3 yaş), 1461-1825 günlük (4 yaş) 1826-2190 günlük (5 yaş), 2191 günlük ve üzeri (6 yaş ve üzeri) olarak sınıflandırıımışlardır.

Hastalık oranları belirlenirken her ırk ve her yaş grubu kendi içinde değerlendirilmiştir. Oranlar hesaplanırken, paya incelenen 5 yıllık süre içerisinde çiftlikte bulunan incelenen yaş ve ırk grubundaki hayvanların en az bir kere incelenen hastalığa yakalananların sayısı; paydaya ise incelenen süre içerisinde çiftlikte bulunan incelenen yaş ve ırk grubundaki toplam hayvan sayısı kullanılmıştır.

\section{İstatistiksel analiz}

Yapılan analizde SPSS Statistics 25 paket programından yararlanılmıştır. İncelenen hastalıkların görülme sıklığı bakımından gruplar (ırk, yaş ve yıl) arasındaki farklııkların analizi için "Ki-kare testi" kullanılmıştır. Alt gruptaki hayvan sayılarının 5 'ten az olduğu durumlarda Fisher'in Kesin Testi Monte Carlo düzeltmesi yapılmıştır. Yapılan analizler sonucunda istatistiki düzeyde farklılığın bulunması için Anlamlııı düzeyi $\mathrm{P}<0.05$ olarak kabul edilmiştir.

\section{Bulgular}

2013-2017 yılları arasında işletmede bulunan 3165 baş düve, 2269 baş 2 yaş, 1830 baş 3 yaş, 1363 baş 4 yaş, 857 baş 5 yaş, 441 baş 6 ve üzeri yaş ineğe ait verilerin hastalık kayıtları incelenmiştir.

İşletmedeki hastalık kayıtlarından, ineklerde genel mastitis görülme oranı \%42 olarak tespit edilmiştir (Tablo 1). Bu oran Siyah Alacalarda \%43.15 ve Simentallerde \%37.46 olarak belirlenmiş olup Siyah alacalarda mastitis görülme oranının daha yüksek olduğu bulunmuştur $(P<0.001)$. Farklı yaş gruplarındaki ineklere bakıldığında ırklar arasındaki farklılıklar değişmektedir. Tablo 1 incelendiğinde 2-3 yaş grubundaki Siyah Alaca ineklerin Simental ineklerden daha fazla mastitis vakası göstermesine rağmen iler-

Tablo 1. İşletmedeki farklı yaş gruplarındaki Siyah Alaca ve Simental ineklerde mastitis görülme oranları (\%)

\begin{tabular}{lllll}
\hline & \multicolumn{2}{c}{ Irk } & P & Genel \\
\cline { 2 - 4 } İnek Yaş Grupları (n) & Siyah Alaca & Simental & $* * *$ & $29.62 \mathrm{c}$ \\
\hline 2 Yaş (2269) & $32.15 \mathrm{c}$ & $18.20 \mathrm{c}$ & - & $40.66 \mathrm{~b}$ \\
$\mathbf{3}$ Yaş (1830) & $40.73 \mathrm{~b}$ & $40.38 \mathrm{~b}$ & - & $52.68 \mathrm{a}$ \\
$\mathbf{4}$ Yaş (1363) & $53.87 \mathrm{a}$ & $48.02 \mathrm{ab}$ & - & $55.96 \mathrm{a}$ \\
$\mathbf{5}$ Yaş (857) & $56.85 \mathrm{a}$ & $49.3 \mathrm{a}$ & - & $53.06 \mathrm{a}$ \\
$\mathbf{6}$ Yaş (441) & $53.49 \mathrm{a}$ & $51.55 \mathrm{a}$ & $* * *$ & 42.00 \\
Genel (5056) & 43.15 & 37.46 & \\
\hline
\end{tabular}

a, b, c; Aynı sütunda farklı harf taşıyan gruplar arasındaki farklııklar istatistiki olarak önemlidir $(P<0.001)$. -: $P>0.05$; $^{* * *}: P<0.001$ 
leyen yaşlarda bu farklıığın ortadan kalktığı görülmektedir $(P<0.01)$. İneklerde mastitisin yaşa bağlı olarak değiştiği ve 4 yaşından itibaren belirgin derecede mastitis oranının arttığı belirlenmiştir.

İşletmedeki kayıtlardan metritis görülme oranı \% 38.72 olarak bulunmuştur (Tablo 2). Siyah Alaca ve Simentallerde metritis görülme oranı sırasıyla \%40.9 ve $\% 28.5$ olarak belirlenmiş olup aralarında önemli düzeyde istatistiki farklılık belirlenmiştir $(P<0.001)$. Genele bakıldığında Siyah Alaca ineklerde Simental ineklere göre daha yüksek metritis görülme oranı olduğu söylenebilir $(P<0.01)$. oranlarına yönelik değerler Tablo 3'te verilmiştir. Metritis ve mastitis görülme oranı Siyah Alaca düvelerde $\% 1.28$ ve $\% 6.87$; Simental düvelerde $\% 0.19$ ve $\% 1.3$ olarak belirlenmiştir. Siyah Alaca düvelerin Simental düvelere göre daha fazla mastitis ve metritis oldukları görülmektedir $(\mathrm{P}<0.05)$.

İşletmede 2013-2017 arasında ineklerde incelenen mastitis ve metritis görülme oranlarının yıllara göre gösterdiği değişimler Şekil 1'de belirtilmiştir. Yıllara göre gruplar arasındaki farklılıklar istatistiki düzeyde önemli bulunmuştur $(P<0.001)$. İşletme genelinde görülen mastitis ve metritisin 2015 yılında nispeten

Tablo 2. İşletmedeki farklı yaş gruplarındaki Siyah Alaca ve Simental ineklerinde metritis görülme oranları (\%)

\begin{tabular}{lllll}
\hline & \multicolumn{2}{c}{ Irk } & & P \\
\cline { 2 - 3 } İnek Yaş Grupları (n) & Siyah Alaca & Simental & $* * *$ & $41.08 \mathrm{a}$ \\
\hline 2 Yaş (2269) & $46.47 \mathrm{a}$ & $16.75 \mathrm{c}$ & - & $35.68 \mathrm{~b}$ \\
$\mathbf{3}$ Yaş (1830) & $36.41 \mathrm{~b}$ & $32.79 \mathrm{~b}$ & $* *$ & $37.93 \mathrm{ab}$ \\
$\mathbf{4}$ Yaş (1363) & $40.04 \mathrm{~b}$ & $29.75 \mathrm{~b}$ & - & $35.59 \mathrm{~b}$ \\
$\mathbf{5}$ Yaş (857) & $36.14 \mathrm{~b}$ & $33.95 \mathrm{~b}$ & - & $42.40 \mathrm{a}$ \\
$\mathbf{6}$ Yaş (441) & $41.28 \mathrm{ab}$ & $46.39 \mathrm{a}$ & $* * *$ & 38.72 \\
Genel (5056) & 40.90 & 28.50 & \\
\hline
\end{tabular}

$a, b, c ;$ Aynı sütunda farklı harf taşıyan gruplar arasındaki farklılıklar istatistiki olarak önemlidir $(P<0.001)$. -: $P>0.05 ;{ }^{* *}: P<0.01$; ***: $P<0.001$

Yaşa göre metritis oranları incelendiğinde ırka bağlı olarak metritis görülme sıklığında değişme görüldüğü söylenebilir. Siyah Alacalarda 3 yaş altında ve 6 yaşın üzerinde metritis görülme sıklığının daha yüksek olduğu görülürken, Simentallerde 3 yaşından itibaren metritisin arttığı gözlemlenmiştir $(P<0.01)$.

İşletmedeki düvelerde mastitis ve metritis görülme yüksek olduğu, 2013 ve 2014 yıllarında diğer yıllara göre nispeten düşük olduğu görülmektedir.

\section{Tartışma ve Sonuç}

Bu çalışmada Siyah Alacalarda mastitis görülme oranı \%43.15 olarak belirlenmiştir. Bu araştırmada klinik ve subklinik mastitis formları bir arada değerlendirilmiştir. Subklinik mastitis formu klinik forma göre insi-

Tablo 3. İşletmedeki 1-2 yaş aralığındaki düvelerde mastitis ve metritis görülme oranları (\%).

\begin{tabular}{lllll}
\hline & \multicolumn{2}{c}{ Irk (n) } & & Genel \\
\cline { 2 - 4 } Hastalıklar & Siyah Alaca (2634) & Simental (531) & G & 1.1 \\
\hline Mastitis & 1.28 & 0.19 & $* *$ & 5.92 \\
\hline Metritis & 6.87 & 1.3 & $* * *$
\end{tabular}

*: $P<0.05 \quad * * *: P<0.001$

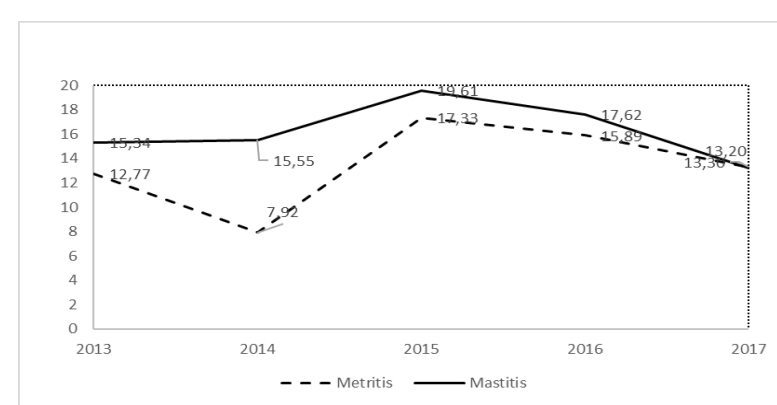

Şekil 1. İşletmedeki ineklerde incelenen mastitis ve metritis görülme oranlarının yıllara göre değişimi. İlgili hastalık bakımından yıllara göre görülen farklılıklar istatistiki düzeyde önemli bulunmuştur $(P<0.001)$. dansı daha yüksek seviyede görülmekte ve süt analiziyle belirlenmektedir (Piepers ve ark., 2007; Roesch ve ark., 2007; Tel ve ark., 2009) İsveç Frizyan ineklerinde mastitis görülme oranının \%14.16 olduğu bildirilmiştir (Oltenacu ve ark., 1990). Kelton ve ark. (1998), 1982 ile 1996 arasında yapılan 62 çalışmanın literatür bilgileri mastitis oranının \%1.7 ile \%14.2 arasında değiştiğini bildirmişlerdir. Barkema ve ark. (1998), Hollanda'da yaptıkları çalışmada Siyah Alacalarda klinik mastitis oranını \%9.8 olarak belirlemişlerdir. Riekerink ve ark. (2008), Kanada'da süt analizlerinden yola çıkarak yaptıkları çalışmada her 100 inekten 23'ünde klinik mastitise sebep olan patojenler tespit etmişlerdir. Hossein-Zadeh ve Ardalan, (2011) İran'daki Siyah Alacalarda \%18.9 oranında mastitis 
görüldüğünü belirlemişlerdir. Türkiye'de 24 sürüdeki 872 sütçü ırk ineğin verilerinin incelenmesi sonucunda mastitis insidansının \%4.6 olduğu bildirilmiştir (Suthar ve ark., 2013). İncelenen literatürlerin hemen hemen hepsinde klinik formdaki mastitis görülme oranına bakılmışken bu çalışmada incelenen yıllarda subklinik formda tespit edilen mastitisli inekler de çalışmaya dahil edildiğinden oranın yüksek çıkmasına neden olmuştur. Aynı zamanda mastitis insidansı işletmelerin çevre şartlarına ve hijyen durumlarına bağlı olarak değişebilmektedir (Bradley, 2002; Ruegg, 2003). Ayrıca barınak sistemleri, teşhis yöntemleri, sağım sistemleri, sağım sayısı ve sağım metodu farklılıkları da sürülerdeki mastitis insidansını etkileyebilmektedir (Suthar ve ark., 2013). Bu işletmede 2017 yılına kadar durak bulunmaması ve ineklerin kendi dışkıları üzerine yatmaları nedeniyle çevresel patojenlere daha fazla maruz kalabilecekleri göz önünde bulundurulmalıdır.

Siyah Alacalarda mastitis görülme oranının yaşla birlikte arttığı görülmektedir $(\mathrm{P}<0.001)$. Siyah Alacalarla mastitis görülme oranı ile ilgili yapılan çalışmalarda Suthar ve ark. (2013), mastitis insidansının doğurma sayısına bağlı olarak arttığını bildirirlerken, Yeni Zelanda'da yapılan bir araştırmada laktasyonun ilk 4 aylık döneminde klinik mastitis oranı ilkine doğuran düvelerde $\% 13.6$ ve ineklerde $\% 9$ olarak belirlenmiştir (Parker ve ark., 2007).

Siyah Alacalarda metritis görülme oranı \%40.9 bulunmuş olup bu kadar yüksek görülmesinin nedeni olarak yapılan hesaplamalarda metritis çeşitlerinin tek bir başlık altında toplanıp bu şekilde değerlendirilmesi olabilir. Örneğin LeBlanc, (2008) klinik endometritisin genel olarak sütçü ırk ineklerin \%10-15'ini etkilerken subklinik formunun \%30-35'lere çıktığını belirtmişlerdir. Doğumdan sonra sütçü ırk ineklerin \%25-40'ının klinik metritise yakalandığı ve \%20'sinin de klinik endometritis olarak devam ettiği bildirilmiştir (Sheldon ve ark., 2008). İsveç Frizyan ırkı ineklerde yapılan bir çalışmada $\% 3.23$ oranında metritis görülmüştür (Oltenacu ve ark., 1990). Bartlett ve ark. (1986), 22 sürüden elde ettikleri sonuçlara göre laktasyon boyunca metritis insidansının \%3 ile \%45 arasında değiştiğini belirtmişlerdir. Kelton ve ark. (1998), 19791995 arasında yayınlanan literatürlerde metritis görülme oranının \%2.2 ile 37.3 arasında değiştiğini belirlemişlerdir. Bruun ve ark. (2002), Danimarka'da 391 sürüde metritis insidansının \%1-21 arasında değiştiğini, Benzaquen ve ark. (2007), ise ABD Florida'da puerperal metritis ile klinik endometritis oranının \%21 ve \%24 olduğunu bildirmişlerdir. Hossein-Zadeh ve Ardalan, (2011) Iran'da Siyah Alacalarda metritis insidansını $\% 8$ olarak belirlemişlerdir. Türkiye'de 24 sürüdeki 872 sütçü ırk ineğin verilerinin incelendiği bir çalışmada metritis insidansı \%3.7 olarak hesaplanmıştır (Suthar ve ark., 2013).

İşletmede 2-3 yaş aralığındaki Siyah Alaca ineklerde metritis oranının daha fazla olduğu görülmektedir $(P<0.01)$. Bunun sebebi doğuran düvelerin uterus duvarının ineklerinkine göre daha hassas olması sonucu hasar riskinin artmasına bağlanabilir (Bruun ve ark., 2002). Aynı zamanda ilkine buzağılayan ineklerde güç doğum riskinin daha fazla olduğu çeşitli literatürlerde belirtilmiştir (Sieber ve ark., 1989; Johanson ve Berger, 2003; Lombard ve ark., 2007; Uzmay ve ark., 2010). Güç doğumun metritis oranını arttırması da ilkine buzağılayan düvelerde metritis oranının yüksek olmasının sebeplerinden biri olarak açıklanabilir (Oltenacu ve ark., 1990). Aynı zamanda 6 yaşından itibaren Siyah Alacalarda metritis görülme oranında ciddi bir artış görülmektedir. Benzer şekilde Markusfeld, (1987) yaptığı çalışma sonucunda Siyah Alacalarda yaşa bağlı doğurma sayısı ile metritis arasında pozitif ilişki olduğunu belirlemiştir.

Sonuç olarak mastitis ve metritisin ilk buzağılamaya kadar ciddi bir problem olarak görülmediği bildirilmiştir. Mastitis, özellikle 4 yaşından itibaren ciddi problem olarak görülmeye başlanmıştır. Metritis ise 3 yaşındaki genç ineklerde ve 6 yaşından büyük yaşı ineklerde artmaktadır. Siyah Alaca ırkı sığırların Simentallere göre mastitis ve metritise daha hassas oldukları görülmektedir. Literatürler arası hastalık oranları bakımından görülebilen farklılıklar; verilerin sadeleştirilmesi ve veri analizi yöntemlerinden kaynaklanmaktadır. Yapılan çalışma ile benzer literatürlerdeki yetiştirme hastalıkları arasında bulunan farklılıklar çalışmaların yapıldığı bölgelerde yerel kaynaklar, kültür yapısı, işletmelerin yönetim yapısı ve pazarlama faktörlerindeki farklılıklara dayandırılabilir. Aynı zamanda bir hastalığın görülme sıklığının belirlenmesi için hastalığın tanımına uygun bir şekilde doğru teşhisin yapılması ve hastalığın şiddetinin uygun şekilde analiz edilip kaydedilmesi gerekmektedir. Araştırıcıların bu konuda çalışmalarını yaygınlaştırması ve kapsamlı çalışmalar yapmaları önerilmektedir.

\section{Teşekkür}

Çalışmanın yapılmasındaki desteklerinden ötürü NiĞTAŞ Ovacık Süt Sığırı İşletmesi'ne teşekkürlerimizi sunarız.

\section{Kaynaklar}

Alaçam E, Tekeli T, Erganiş O, İzgi A. İnek ve mandalarda subklinik mastitislerin tanısı, etkenlerin izolasyonu ve bunlara karşı etkili antibiyotiklerin belirlenmesi. SÜ Vet Fak Derg 1989; 5(1): 91-101.

Barkema $H$, Schukken $Y$, Lam T, Beiboer M, Wilmink $H$, Benedictus $G$, Brand $A$. Incidence of clinical mastitis in dairy herds grouped in three categories by bulk milk somatic cell counts. J Dairy Sci 1998; 81(2): 411-9.

Bartlett PC, Kirk JH, Wilke MA, Kaneene JB, Mather 
EC. Metritis complex in Michigan Holstein-Friesian cattle-ıncidence, descriptive epidemiology and estimated economic-impact. Prev Vet Med 1986; 4(3): 235-48.

Benzaquen M, Risco C, Archbald L, Melendez P, Thatcher MJ, Thatcher W. Rectal temperature, calving-related factors, and the incidence of puerperal metritis in postpartum dairy cows. J Dairy Sci 2007; 90(6): 2804-14.

Bradley, AJ. Bovine mastitis: An evolving disease. Vet J 2002; 164(2): 116-28.

Bruun J, Ersbøll A, Alban L. Risk factors for metritis in Danish dairy cows. Prev Vet Med 2002; 54(2): 179-90.

Contreras GA, Rodriguez JM. Mastitis: Comparative etiology and epidemiology. J Mammary Gland Biol Neoplasia 2011, 16(4): 339-56.

Hossein-Zadeh NG, Ardalan M. Cow-specific risk factors for retained placenta, metritis and clinical mastitis in Holstein cows. Vet Res Commun 2011; 35(6): 345-54.

Johanson J, Berger P. Birth weight as a predictor of calving ease and perinatal mortality in Holstein cattle. J Dairy Sci 2003; 86(11): 3745-55.

Kelton DF, Lissemore KD, Martin RE. Recommendations for recording and calculating the incidence of selected clinical diseases of dairy cattle. J Dairy Sci 1998; 81(9): 2502-9.

Kuyucuoğlu Y, Uçar M. Afyon bölgesi süt ineklerinde subklinik ve klinik mastitislerin görülme oranları ve etkili antibiyotiklerin tespiti. Vet Hek Mikrobiyol Derg 2001; 1: 19-24.

LeBlanc SJ. Postpartum uterine disease and dairy herd reproductive performance: $A$ review. Vet $\mathrm{J}$ 2008; 176(1): 102-14.

Lombard J, Garry F, Tomlinson S, Garber L. Impacts of dystocia on health and survival of dairy calves. J Dairy Sci 2007; 90(4): 1751-60.

Markusfeld O. Periparturient traits in seven high dairy herds. Incidence rates, association with parity, and interrelationships among traits. J Dairy Sci 1987; 70 (1): 158-66.

McDougall, S. Prevalence of clinical mastitis in 38 Waikato dairy herds in early lactation. New Zealand Vet J 1999; 47(4): 143-9.

Oltenacu PA, Frick A, Lindhé B. Epidemiological study of several clinical diseases, reproductive performance and culling in primiparous Swedish cattle. Prev Vet Med 1990; 9(1): 59-74.
Parker K, Compton C, Anniss F, Weir A, McDougall $S$. Management of dairy heifers and its relationships with the incidence of clinical mastitis. New Zealand Vet J 2007; 55(5): 208-16.

Petrovski K, Heuer C, Parkinson T, Williamson N. The incidence and aetiology of clinical bovine mastitis on 14 farms in Northland, New Zealand. New Zealand Vet J 2009; 57(2): 109-15.

Piepers S, De Meulemeester L, de Kruif A, Opsomer G, Barkema HW, De Vliegher S. Prevalence and distribution of mastitis pathogens in subclinically infected dairy cows in Flanders, Belgium. J Dairy Res 2007; 74(4): 478-83.

Riekerink RGMO, Barkema HW, Kelton DF, Scholl DT. Incidence rate of clinical mastitis on Canadian dairy farms. J Dairy Sci 2008; 91(4): 1366-77.

Roesch M, Doheer MG, Scharen W, Schallibaum M, Blum JW. Subclinical mastitis in dairy cows in Swiss organic and conventional production systems. J Dairy Res 2007; 74(1): 86-92.

Ruegg, PL. Investigation of mastitis problems on farms. Veterinary Clinics: Food Anim Pract 2003, 19(1): 47-73.

Sheldon IM, Williams EJ, Miller AN, Nash DM, Herath $\mathrm{S}$. Uterine diseases in cattle after parturition. Vet $J$ 2008; 176(1): 115-21.

Sieber M, Freeman A, Kelley D. Effects of body measurements and weight on calf size and calving difficulty of Holsteins. J Dairy Sci 1989; 72(9): 2402-10.

Stevenson MA. Disease incidence in dairy herds in the southern highlands district of New South Wales, Australia. Prev Vet Med 2000; 43(1): 1-11.

Suthar V, Canelas-Raposo J, Deniz A, Heuwieser W. Prevalence of subclinical ketosis and relationships with postpartum diseases in European dairy cows. J Dairy Sci 2003; 96(5): 2925-38.

Şahin M, Çolak A, Otlu S, Aydın F, Genç O, Güler M, Oral $\mathrm{H}$. Kars yöresi ithal Simental ineklerinde subklinik ve klinik mastitislerin görülme oranları ve etkili antibiyotiklerin belirlenmesi. Kafkas Üniv Vet Fak Derg 1997, 3(1): 49-55.

Tel OY, Keskin O, Zonturlu AK, Kaya NBA. Şanlıurfa yöresinde subklinik mastitislerin görülme oranı, aerobik bakteri izolasyonu ve duyarlı antibiyotiklerin belirlenmesi. FÜ Sağ Bil Vet Derg 2009; 23: 101-6.

Uzmay C, Kaya I, Ayyilmaz T. Analysis of risk factors for dystocia in a Turkish Holstein herd. J Anim Vet Advances 2010, 9: 2571-7. 